\title{
Synthesis, Spectral and Biological Studies of Complexes with Bidentate Azodye Ligand Derived from Resorcinol and 1-amino-2-naphthol-4-sulphonic Acid
}

\author{
V. G. VIDYA ${ }^{1 *}$, V. SADASIVAN ${ }^{1}$, S. S. MEENA ${ }^{2}$ and PRAMOD BHATT ${ }^{2}$ \\ 1University College, M G Road, Palayam, Thiruvananthapuram- 695 034, Kerala, India. \\ 2Solid State Physics Division, Bhabha Atomic Research Centre, Mumbai 400 085, India. \\ ${ }^{\star}$ Corresponding author E-mail: vg_vidya @yahoo.co.in
}

http://dx.doi.org/10.13005/ojc/340105

(Received: August 30, 2017; Accepted: September 15, 2017)

\begin{abstract}
A new series of transition metal complexes of $\mathrm{Mn}(\mathrm{II}), \mathrm{Fe}(\mathrm{II}), \mathrm{Co}(\mathrm{II}), \mathrm{Ni}(\mathrm{II}), \mathrm{Cu}(\mathrm{II}), \mathrm{Zn}(\mathrm{II})$, and $\mathrm{Fe}$ (III) with the azo dye, 3-hydroxy-4-(2,4-dihydroxyphenylazo)naphthalene-1-sulphonic acid (LH) have been synthesized and characterized. The structural features have been arrived from their microanalysis, magnetic susceptibility, molar conductance measurements, mass, fluorescence, IR, UV-Vis, ${ }^{1} \mathrm{HNMR}$ and ESR spectral studies. Mössbauer spectra of two iron complexes have been done. In the light of these results, it is suggested that ligand coordinates to metal ions via hydroxyl oxygen and nitrogen of azo group. The fluorescence spectral property of ligand and complexes studied where complexes shows enhanced emission. The redox property of the Co(II) complex is studied by cyclic voltammetry. The ligand and its $\mathrm{Mn}$ (II) complex was investigated for non linear optical property. The in vitro biological activity of the ligand and complexes were tested against Escherichia coli, Staphylococcus aureus, Aspergillus niger and Candida albicans. The results indicate that the complexes have enhanced biological activity than the ligand. Antioxidant activity of the ligand and complexes was studied by free radical scavenging method. The nuclease activity of ligand and complexes show that they cleave DNA through redox chemistry.
\end{abstract}

Keywords: Azo dye, Mössbauer spectra, NLO property, DNA cleavage, Antioxidant activity.

\section{INTRODUCTION}

In the last few years, a lot of interest have been taken by chemists in the synthesis and physicochemical studies of first row transition metal complexes with a number of azo dye ligands ${ }^{1}$. Azo dyes readily form stable complexes with most of the transition metals that plays an important role in the development of coordination chemistry ${ }^{2}$. Azo dyes have massive applications in various fields of science and technology they serve as a class of widely used colouring materials ${ }^{3}$. They play a major role in textile, printing, leather, paper making, drugs ${ }^{4}$ and in food industries ${ }^{5}$. The

This is an $\mathbf{C}$ Open Access article licensed under a Creative Commons Attribution-NonCommercial-ShareAlike 4.0 International License (https://creativecommons.org/licenses/by-nc-sa/4.0/ ), which permits unrestricted NonCommercial use, distribution and reproduction in any medium, provided the original work is properly cited. 
increasing use of these dyes in electronic industry such as colorimetric sensors, non linear optical (NLO) devices and liquid crystalline displays. They are also used as potential sensitizers for photodynamic therapy ${ }^{6}$. In bioinorganic chemistry, interest in azo dye complexes has centered on the role that complexes play in providing synthetic models for the metal containing sites in metalloproteins and enzymes ${ }^{7,8}$. Metal ions involved in biological processes of life has been a subject of interest $^{9,10}$. The modes of action of metal ions are often complex but are believed to involve bonding with the hetero atoms of the heterocyclic residues of biological molecules.

In the present paper, the synthesis and characterization of a new azo dye and its complexes have been reported. The aim of the study is to understand the spectrochemical and biological activities of this new dye and its complexes.

\section{EXPERIMENTAL}

All reagents and solvents for synthesis and analysis were Merck products and used as supplied. FTIR spectra were recorded using $\mathrm{KBr}$ discs on a Perkin-Elmer Spectrum 65 spectrometer. Elemental analyses performed on a Vario EL-III CHN analyser. Conductivity measurements were made using Systronics direct reading conductivity meter. The magnetic susceptibilities were measured on a magnetic susceptibility balance Sherwood Scientific. Electronic absorption spectral measurements of the ligand and the complexes in methanol were conducted using Perkin-Elmer Lambda 25 UV-Vis spectrophotometer. ${ }^{1} \mathrm{H}$ NMR spectra was recorded on a Bruker Avance III, 400MHz FTNMR instrument using TMS as reference. The fluorescence spectral measurements of ligand and complexes in methanol were recorded on a JASCO750 fluorescence spectrometer. The Mössbauer spectra of iron complexes recorded using Mossbauer Spectrometer Nucleonix Systems, constant acceleration mode at room temperature. The source employed was Co-57 in Rh matrix of strength $50 \mathrm{mCi}$. The velocity scale calibration was done using an enriched $\alpha^{57}$ Fe metal foil of line width $0.23 \mathrm{~mm} / \mathrm{s}$ using a Win-Normos fit program. The voltammetric measurements were carried on a BAS CV-50W voltammetric analyzer. The second harmonic generation (SHG) conversion efficiency of ligand determined by modified version of powder technique.
Preparation of 3-hydroxyl-4-(2,4dihydroxy phenylazo)naphthalene-1-sulphonic acid [LH]

A solution of 1-amino-2-naphthol-4sulphonic acid $(0.01 \mathrm{~mol})$ was prepared in least amount of $\mathrm{HCl}$ and cooled to $0^{\circ} \mathrm{C}$. A cold solution of $\mathrm{NaNO}_{2}$ below $5^{\circ} \mathrm{C}$ was added to the amine solution drop wise with continuous stirring. This cold diazonium salt solution was added to resorcinol solution $(0.01 \mathrm{~mol}$ in $\mathrm{NaOH})$ kept at $0{ }^{\circ} \mathrm{C}$ drop wise with stirring ${ }^{11}$. The dye separated was filtered off and dried in vacuo over anhydrous $\mathrm{CaCl}_{2}$. The purity of azo dye was confirmed by TLC.

\section{Preparation of the complexes}

The complexes of LH were prepared by mixing ethanolic solutions of respective metal salt and LH in molar ratio 1:2. The solution obtained was heated under reflux for $4 \mathrm{~h}$ for completion of the reaction. The solid compound deposited filtered and washed three times with ethanol and dried over silica gel in a desiccator.

\section{RESULTS AND DISCUSSION}

The metal and chloride content of the reported complexes were estimated following standard procedure ${ }^{12}$. Analytical data of complexes and the ligand are presented in Table.1. The elemental analyses shows that complexes has general stoichiometry of type $\left[\mathrm{ML}_{2}\left(\mathrm{H}_{2} \mathrm{O}\right)_{2}\right]$ where $\mathrm{M}=\mathrm{Mn}(\mathrm{II}), \mathrm{Co}(\mathrm{II}), \mathrm{Ni}(\mathrm{II}), \mathrm{Fe}(\mathrm{II}), \mathrm{Cu}(\mathrm{II}),\left[\mathrm{ZnL}_{2}\right]$ and $\left[\mathrm{FeL}_{2} \mathrm{Cl}\left(\mathrm{H}_{2} \mathrm{O}\right)\right]$.

The ligand and its metal complexes are air stable, soluble in DMSO and DMF.

The ${ }^{1} \mathrm{H}-\mathrm{NMR}$ spectra of $\mathrm{LH}$ and its $\mathrm{Zn}(\mathrm{II})$ complex were recorded in d6-DMSO solution on a $400 \mathrm{MHz}$ FTNMR spectrometer using TMS as the reference material. The ${ }^{1} \mathrm{H}-\mathrm{NMR}$ of $\mathrm{LH}$ shows a multiplet between $\delta 6.1-7.7 \mathrm{ppm}(8 \mathrm{H}, \mathrm{m})$ due to aryl protons. The peaks respectively at $\delta 8.7 \mathrm{ppm}(1 \mathrm{H}, \mathrm{s})$, $\delta 11.1(1 \mathrm{H}, \mathrm{s})$ and $\delta 9.3(1 \mathrm{H}, \mathrm{s})$ are assignable to $\mathrm{OH}$ of resorcinol and naphthol group. The singlet observed at $\delta 11.1 \mathrm{ppm}$ due to one - group in LH is absent in the $\mathrm{Zn}(\mathrm{II})$ complex indicating deprotonation of one hydroxyl group before coordination to metal ion. The two other - protons were shifted to lower field. This indicates that among three phenolic - group one gets deprotonated and coordinated to $\mathrm{Zn}$ (II) and others remain as such. The values of aryl protons were also shifted to lower field indicating chelation of ligand. The singlet at $\delta$ $2.51 \mathrm{ppm}$ corresponds to proton of sulfonic acid group in the LH shifted to lower field of $\delta 2.72 \mathrm{ppm}^{13}$. 
The ${ }^{1} \mathrm{H}-\mathrm{NMR}$ spectrum of $\mathrm{LH}$ and $\left[\mathrm{ZnL}_{2}\right]$ is given in Figure. 1 and Figure.2.

The ESI mass spectra of the LH shows a molecular ion peak at $\mathrm{m} / \mathrm{z}=361$ shown in Fig. 3 . The mass spectrum of $\left[Z n L_{2}\right]$ shows a $(M+1)$ peak

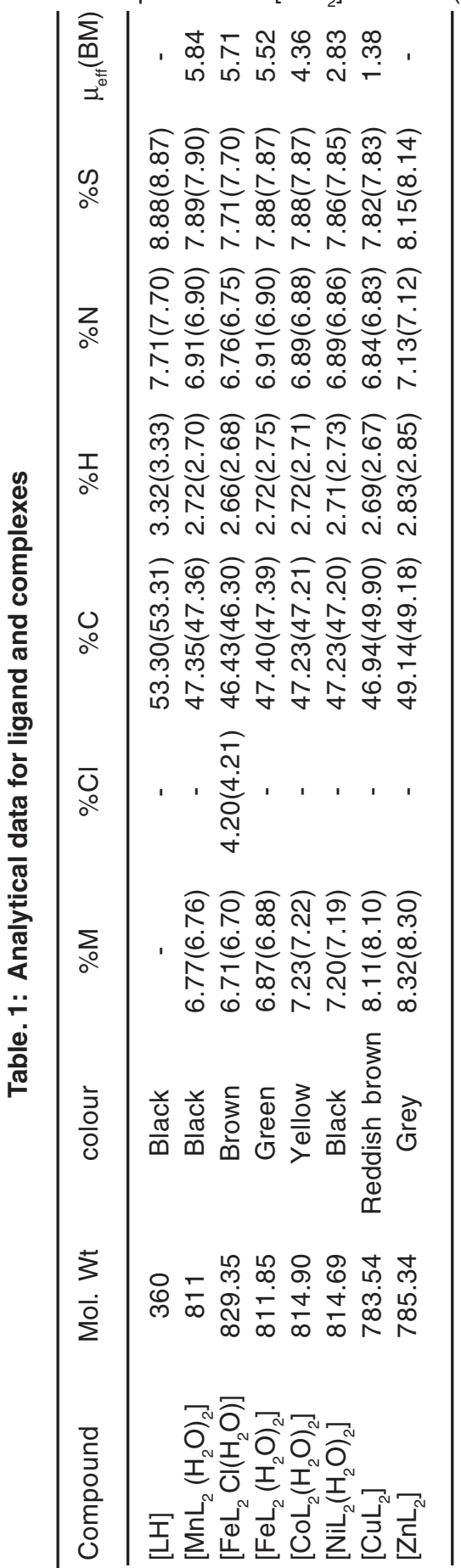

at $\mathrm{m} / \mathrm{z} 784$ and $(\mathrm{M}+\mathrm{Na})$ peak at $\mathrm{m} / \mathrm{z} 806$ confirms its stoichiometry. Mass spectrum of $\left[\mathrm{ZnL}_{2}\right]$ is shown in Figure. 4.

The molar conductance of the complexes measured in methanol, DMF and in nitrobenzene supports the non electrolytic nature.

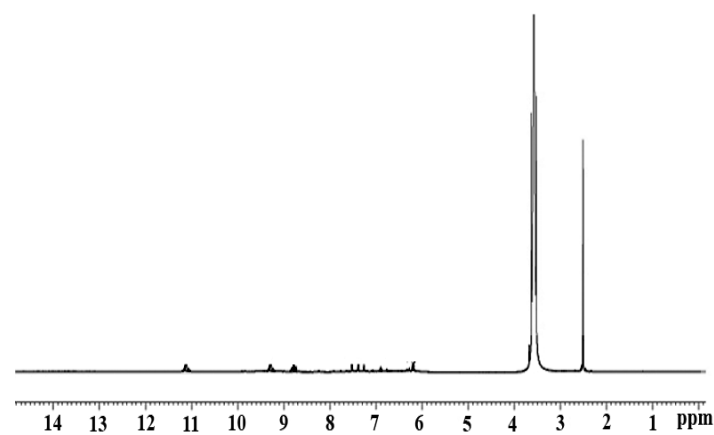

Fig.1. ${ }^{1} \mathrm{H}-\mathrm{NMR}$ spectra of [LH]

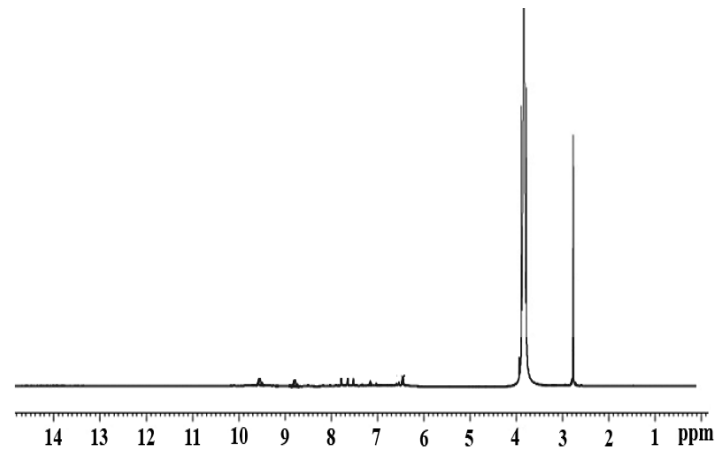

Fig 2. ${ }^{1} \mathrm{H}-\mathrm{NMR}$ spectra of $\left[\mathrm{ZnL}_{2}\right]$

Azo dyes are not only mere dyestuffs but also used in photodynamic therapy. There are recent reports on the photoluminescence properties of azo dyes, which are potential systems for photodynamic therapy ${ }^{14}$. $\mathrm{LH},\left[\mathrm{MnL}_{2}\left(\mathrm{H}_{2} \mathrm{O}\right)_{2}\right]$ and $\left[\mathrm{NiL}_{2}\left(\mathrm{H}_{2} \mathrm{O}\right)_{2}\right]$ exhibit fluorescence in the range $350-700 \mathrm{~nm}$ in methanol solution at room temperature. These are assigned

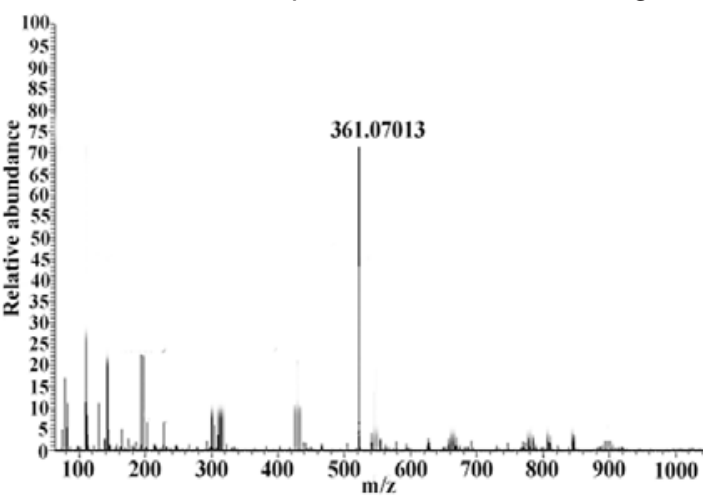

Fig 3. Mass spectra of [LH] 


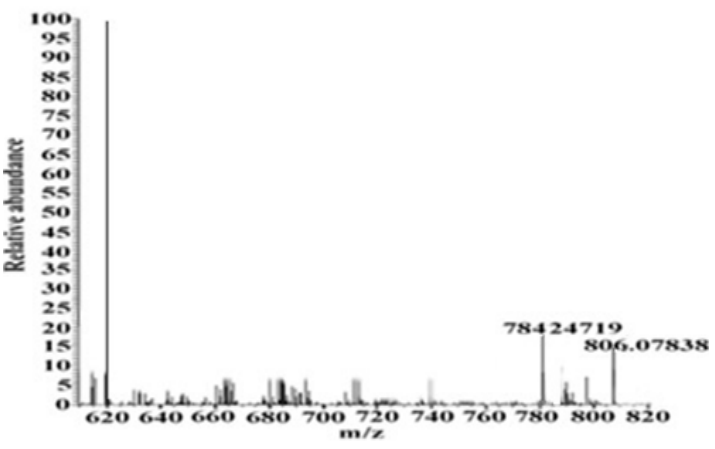

Fig 4. Mass spectra of $\left[\mathrm{ZnL}_{2}\right]$

as intraligand $(\pi \rightarrow \pi *)$ fluorescence. It is interesting that $\mathrm{Mn}(\mathrm{II})$ and $\mathrm{Ni}(\mathrm{II})$ complexes show enhanced emission than that of free ligand. Metal ions can enhance the fluorescence emission of azo dye. The fluorescence spectra of $\mathrm{LH},\left[\mathrm{MnL}_{2}\left(\mathrm{H}_{2} \mathrm{O}\right)_{2}\right]$ and $\left[\mathrm{NiL}_{2}\left(\mathrm{H}_{2} \mathrm{O}\right)_{2}\right]$ are given in Fig 5 . LH shows two emission bands at 470 and $594 \mathrm{~nm}$ when excited at $320 \mathrm{~nm}$. $\left[\mathrm{MnL}_{2}\left(\mathrm{H}_{2} \mathrm{O}\right)_{2}\right]$ shows emission at $407 \mathrm{~nm}$ and $\left[\mathrm{NiL}_{2}\left(\mathrm{H}_{2} \mathrm{O}\right)_{2}\right]$ shows two bands at 409 and 569 $\mathrm{nm}$ when excited at 353 and $360 \mathrm{~nm}$ respectively.

The infrared spectra of $\mathrm{LH}$ and its metal complexes were recorded in the range $400-4000 \mathrm{~cm}^{-1}$. The infrared spectra of the complexes show characteristic absorptions of all functional groups of the ligand but at shifted position in the case of coordinated groups of the ligand.

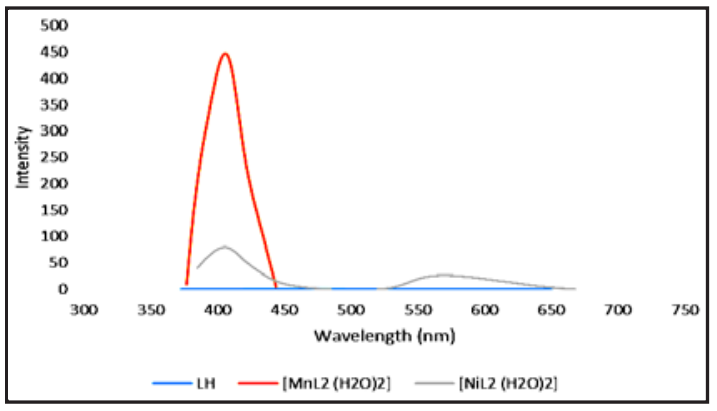

Fig. 5. Photoluminescence spectra of [LH]
The $-\mathrm{N}=\mathrm{N}$ - stretching vibration of $\mathrm{LH}$ at $1459 \mathrm{~cm}^{-1}$ shifted to $1431-1438 \mathrm{~cm}^{-1}$ in its complexes indicating the azo group participation in coordination. All the complexes show additional band around $416-432 \mathrm{~cm}^{-1}$ due to $\mathrm{M}-\mathrm{N}$ coordination. The Stretching in $\mathrm{LH}$ complexes appears respectively at $3429 \mathrm{~cm}^{-1}, 3436 \mathrm{~cm}^{-1}$ and $3420 \mathrm{~cm}^{-1}$ as broad band is due to hydrogen bonded hydroxyl groups. In the IR spectra of the complexes the disappearance of the band at $3420 \mathrm{~cm}^{-1}$ indicates deprotonation of one $\mathrm{OH}$ group. This infers that one $\mathrm{OH}$ gets coordinated after deprotonation and others remain as such. The appearance of a new broad band around $3443 \mathrm{~cm}^{-1}$ in complexes indicates the presence of water molecule. The presence of coordinated water molecule is again confirmed by the presence of two other bands within the ranges 1630-1600 and 970-950 $\mathrm{cm}^{-1}$ due to $\mathrm{HOH}$ deformation and rocking. A band observed in range $1201-1216 \mathrm{~cm}^{-1}$ is due to the symmetric stretching vibration of $-\mathrm{SO}_{3} \mathrm{H}$ group. The appearance of new bands in the region $510-523 \mathrm{~cm}^{-1}$ and $415-435 \mathrm{~cm}^{-1}$ due to $v_{M-O}$ and $v_{M-N}$ supports the coordination of $\mathrm{OH}$ group and $-\mathrm{N}=\mathrm{N}$ - group to metal ions ${ }^{15}$. The IR spectral evidences discussed so far indicate that the ligand is coordinated to the metal ion in uninegative bidentate manner. IR spectral data of $\mathrm{LH}$ and complexes are given in Table. 2.

The electronic spectra of ligand shows two absorption maxima at $320 \mathrm{~nm}$ and $340 \mathrm{~nm}$ corresponding to $\mathrm{n} \rightarrow \pi *$ and $\pi \rightarrow \pi^{*}$ transitions and undergoes bathochromic shift upon coordination.

The spectrum of $\mathrm{Cu}$ (II) complex shows a shoulder in $462 \mathrm{~nm}$ due to ${ }^{2} \mathrm{~A}_{1 \mathrm{~g}} \rightarrow{ }^{2} \mathrm{~B}_{1 \mathrm{~g}} \mathrm{~d}$-d transition. The observed magnetic moment of this complex is 1.38 BM. This subnormal effective magnetic moment value indicates that the copper centres are ferromagnetically coupled ${ }^{16}$. The $\mathrm{Ni}(\mathrm{II})$ complex exhibits weak bands at $520 \mathrm{~nm}$ and $588 \mathrm{~nm}$ corresponds to ${ }^{3} A_{2 g}(F) \rightarrow{ }^{3} T_{1 g}(P)$ and ${ }^{3} A_{2 g}(F) \rightarrow{ }^{3} T_{1 g}$

Table 2. Selected FT-IR data for ligand and its complexes $\left(\mathrm{cm}^{-1}\right)$

\begin{tabular}{|c|c|c|c|c|c|c|c|c|}
\hline $\begin{array}{l}\text { 至 } \\
\end{array}$ & 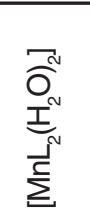 & 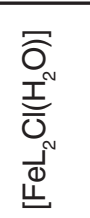 & 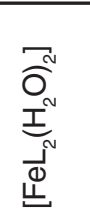 & $\begin{array}{l}\widetilde{O}^{N} \\
\underline{I}^{N} \\
\tilde{O}^{N} \\
0\end{array}$ & $\begin{array}{l}\widetilde{O}^{N} \\
\underline{I}^{N} \\
\vec{n}^{n} \\
\underline{Z}\end{array}$ & 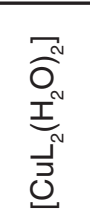 & $\frac{\vec{N}}{\stackrel{N}{N}}$ & 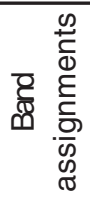 \\
\hline 3420 & - & - & - & - & - & - & - & $v_{\mathrm{OH}}$ \\
\hline - & 3447 & 3446 & 3447 & 3445 & 3444 & 3434 & - & $v_{\mathrm{H} 2 \mathrm{O}}$ \\
\hline 1459 & 1435 & 1431 & 1438 & 1438 & 1435 & 1432 & 1433 & $v_{\mathrm{N}=\mathrm{N}}$ \\
\hline - & 515 & 510 & 523 & 517 & 518 & 520 & 518 & $v_{M-O}$ \\
\hline- & 417 & 416 & 432 & 418 & 420 & 422 & 418 & $v_{M-N}$ \\
\hline
\end{tabular}


(F) transitions. The magnetic moment of this complex is $2.83 \mathrm{BM}$ suggesting an octahedrally coordinate $\mathrm{Ni}(\mathrm{II})$ complex. The $\mathrm{Co}(\mathrm{II})$ complex exhibit peaks at $477 \mathrm{~nm}$ and $675 \mathrm{~nm}$ for ${ }^{4} \mathrm{~T}_{1 \mathrm{~g}}(\mathrm{~F}) \rightarrow{ }^{4} \mathrm{~T}_{1 \mathrm{~g}}(\mathrm{P})$ and ${ }^{4} T_{1 g}(F) \rightarrow{ }^{4} A_{2 g}(F)$ transitions. The magnetic moment value of $4.36 \mathrm{BM}$ also indicates an octahedral geometry for the complex. The Fe(III) complex exhibits band at $660 \mathrm{~nm}$ and $680 \mathrm{~nm}$ assigned to ${ }^{6} \mathrm{~A}_{1 \mathrm{~g}} \rightarrow{ }^{4} \mathrm{~T}_{2 \mathrm{~g}}$ and ${ }^{6} \mathrm{~A}_{1 \mathrm{~g}} \rightarrow{ }^{4} \mathrm{~T}_{1 \mathrm{~g}}$ transitions. The magnetic moment value of $5.71 \mathrm{BM}$ agrees to the octahedral high spin geometry of complex. The $\mathrm{Fe}$ (II) complex exhibit bands at $510 \mathrm{~nm}$ and 660 $\mathrm{nm}$ due to ${ }^{5} \mathrm{~T}_{2 \mathrm{~g}} \rightarrow{ }^{5} \mathrm{E}_{\mathrm{g}}$ transitions. This complex has an octahedral high spin state with a magnetic moment value of $5.52 \mathrm{BM}$. The $\mathrm{Mn}$ (II) exhibits a band at $474 \mathrm{~nm}$ due to $\mathrm{d}-\mathrm{d}$ transition. The magnetic moment is $4.84 \mathrm{BM}$ suggesting a distorted octahedral geometry ${ }^{18}$.

The X-band ESR spectrum of copper complex was recorded at $77 \mathrm{~K}$ is shown in Fig. 6 . The frozen solution shows a well resolved four line hyperfine splitting in parallel region corresponds to the electron spin -nuclear spin interaction. The absence of half field signal at 1600G, corresponding to $\Delta \mathrm{M}_{\mathrm{s}}= \pm 2$ transition, rules out any $\mathrm{Cu}-\mathrm{Cu}$ interaction in ESR spectra. The frozen solution shows a well resolved four line hyperfine splitting in parallel region corresponding to the electron spin -nuclear spin interaction. The $\mathrm{Cu}$ complex exhibits two different $g$ values, indicating the magnetic anisotropy in the complex. It exhibits two different $g$ values, indicating the magnetic anisotropy in the complex. The spin Hamiltonian parameters, calculated for the complex are given in Table. 3. The g tensor values of the $\mathrm{Cu}$ (II) complex can be used to derive the ground state.

The $g_{\|}(2.41)>g_{\perp}(2.06)>g_{e}(2.0027)$ indicates that the complex has an axially elongated octahedral geometry. Further it is supported from the fact that the unpaired electron lies predominantly in $d_{x 2-y 2}$ orbital as was evident from the value of exchange interaction term, G. The perpendicular component shows no hyperfine splitting $A \perp \approx "=" 0$. The covalency factor $\alpha^{2}$ calculated for the complex is 0.86 , less than one indicates that the complex has some covalent character in ligand environment.

If $G>4$, local tetragonal axes are aligned parallel or only slightly misaligned. The observed value for exchange interaction parameter for the $\mathrm{Cu}$ complex ( $\mathrm{G}=7.11$ ) suggests that the local tetragonal axes are aligned parallel or slightly misaligned. The $g$ values are taken to calculate the exchange interaction, if $\mathrm{G}>4$, the exchange coupling is negligible ${ }^{19}$.

Table. 3: Electron Spin Resonance parameters of copper complex

\begin{tabular}{lcccccc}
\hline Complex & $g_{\|}$ & $g_{\perp}$ & $g_{\text {avg }}$ & $A_{\|}$ & $G$ & $\alpha^{2}$ \\
\hline $\left.\mathrm{CuL}_{2}\right]$ & 2.41 & 2.06 & 2.17 & 140 & 7.11 & 0.86 \\
\hline
\end{tabular}

The cyclic voltammogram of the Co complex in $\mathrm{MeCN}$ in potential range 1.5 to $-1.5 \mathrm{~V}$ shows a well defined redox process corresponding to the formation of $\mathrm{Co}(\mathrm{II}) / \mathrm{Co}(\mathrm{I})$ couple. A reduction peak at $\mathrm{E}_{\mathrm{pa}}=-0.39 \mathrm{~V}$ and at $\mathrm{E}_{\mathrm{pc}}=-0.656 \mathrm{~V}$. This couple is found to be reversible with $\Delta \mathrm{E}_{\mathrm{p}}=0.266 \mathrm{~V}$. The ratio of anodic to cathodic peak currents $\left(I_{\mathrm{pa}} / \mathrm{I}_{\mathrm{pc}}\right.$ $=1$ ) corresponding to one electron process. The

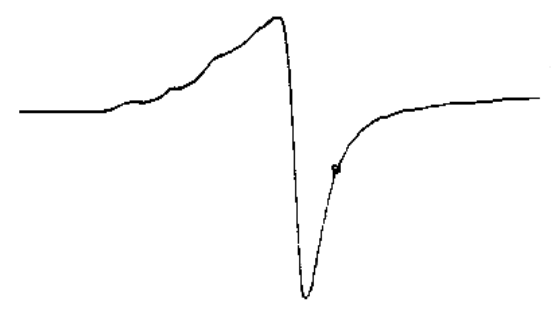

\section{0$$
\mathrm{H} \rightarrow
$$

Fig. 6. ESR spectra of $\left[\mathrm{CuL}_{2}\right]$

complex shows another quasi reversible peak in the anodic region, characteristics of $\mathrm{Co}$ (II) / Co(III) couple at $\mathrm{E}_{\mathrm{pc}}=0.219 \mathrm{~V}$ and at $\mathrm{E}_{\mathrm{pa}}=0.196 \mathrm{~V}$ for $\mathrm{Co}$ (II) $/ \mathrm{Co}$ (III) oxidation with $\Delta \mathrm{E}_{\mathrm{p}} 0.023 \mathrm{~V}$. The voltammetric studies proved that these complexes are relatively more stable. The peak separation of this couple is $0.023 \mathrm{~V}$. The ratio of anodic to cathodic peak currentsH" 1 corresponding to one electron process. The tapering of peak both in cathodic and anodic side may be due to ligand oxidation ${ }^{21}$. The cyclic voltammogram of $\left[\mathrm{CoL}_{2}\left(\mathrm{H}_{2} \mathrm{O}\right)_{2}\right]$ is shown in Figure. 7 .

The Mössbauer spectra of iron complexes were recorded at room temperature and given in Fig. 8 and 9 and Mössbauer parameters in Table. 4

The $\left[\mathrm{FeL}_{2} \mathrm{Cl}\left(\mathrm{H}_{2} \mathrm{O}\right)\right]$ gives a signal with an isomer shift $\delta=0.35 \mathrm{~mm} / \mathrm{s}$. The observed isomer shift value suggests that $\mathrm{Fe}(\mathrm{III})$ nucleus is in high spin state. A single signal indicates presence of some symmetry around $\mathrm{Fe}(\mathrm{III})$ ion in complex ${ }^{22}$. 
$\left[\mathrm{FeL}_{2}\left(\mathrm{H}_{2} \mathrm{O}\right)_{2}\right]$ shows four types of doublet with isomer shift value of $1.48,1.26,0.23$ and 0.40 $\mathrm{mm} / \mathrm{s}$ and quadruple splitting of $2.74,3.29,1.07$ and $1.15 \mathrm{~mm} / \mathrm{s}$ respectively indicating that there are four different species present in complex. The above parameters are characteristic of octahedrally coordinated high spin $\mathrm{Fe}(\mathrm{II})$ complex. The isomer shift does not indicate a similar electron density around the iron atom. The values are consistent of iron (II) high spin configuration and are in agreement with magnetic moment value $4.52 \mathrm{BM}^{23,24,25,26,27,28}$.

The LH (L3), $\left[\mathrm{MnL}_{2}\left(\mathrm{H}_{2} \mathrm{O}\right)_{2}\right](\mathrm{M} 3),\left[\mathrm{NiL}_{2}\right.$ $\left(\mathrm{H}_{2} \mathrm{O}_{2}\right](\mathrm{N} 3)$ and $\left[\mathrm{ZnL}_{2}\right](\mathrm{Z3})$ complexes were tested for their inhibitory activity on antimicrobial growth by a modified disc diffusion method against

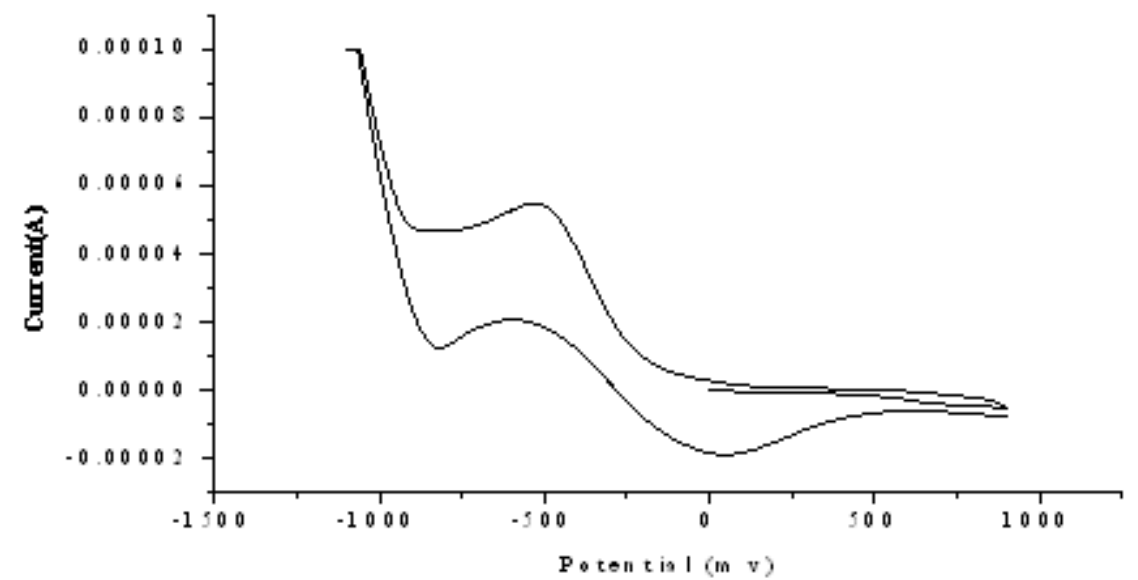

Fig. 7. $\mathrm{CV}$ of $\left[\mathrm{CoL}_{2}\left(\mathrm{H}_{2} \mathrm{O}\right)_{2}\right]$

Escherichia coli, Staphylococcus aureus, Aspergillus niger and Candida albicans. The standard drugs clotrimazole and gentamycin were taken as the standard. From the results it is clear that the inhibition zone of the complex is higher than that of the ligand. The higher activity of complexes can be explained by chelation ${ }^{29}$. The results are given in Figure.10.

The antioxidant activities of these compounds are expressed as $50 \%$ inhibitory concentration $\left(\mathrm{IC}_{50}\right.$ in $\left.\mu \mathrm{g} / \mathrm{ml}\right)$ shown in Fig.11. $\mathrm{IC}_{50}$ values of $\mathrm{LH},\left[\mathrm{MnL}_{2}\left(\mathrm{H}_{2} \mathrm{O}\right)_{2}\right](\mathrm{M} 3)$ and $\left[\mathrm{NiL}_{2}\left(\mathrm{H}_{2} \mathrm{O}\right)_{2}\right]$ (N3) are $187 \pm 0.25,166 \pm 0.13$, and $185 \pm 0.12 \mu \mathrm{g} / \mathrm{ml}$ respectively. Mn complex shows better inhibitory action than ligand ${ }^{30}$.

The DNA gel electrophoresis experiment was conducted at room temperature using ligand and complexes in presence of $\mathrm{H}_{2} \mathrm{O}_{2}$ as oxidant (Fig.12). Both ligand (L3) and its $\mathrm{Ni}(\mathrm{II})$ (N3) and $\mathrm{Mn}$ (II)

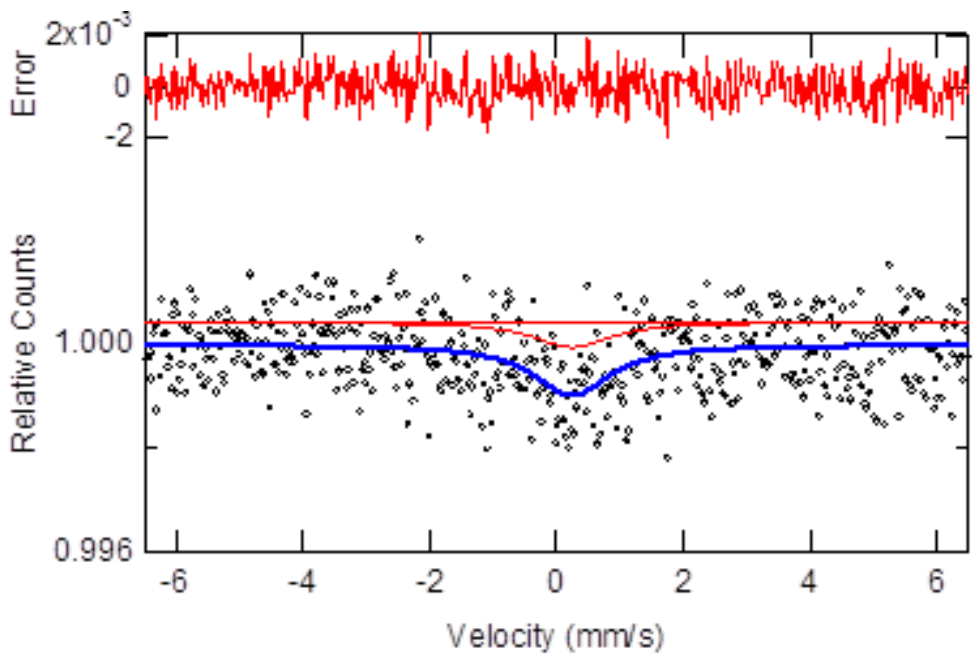

Fig. 8. Mössbauer spectra of $\left[\mathrm{FeL}_{2} \mathrm{Cl}\left(\mathrm{H}_{2} \mathrm{O}\right)\right]$ 


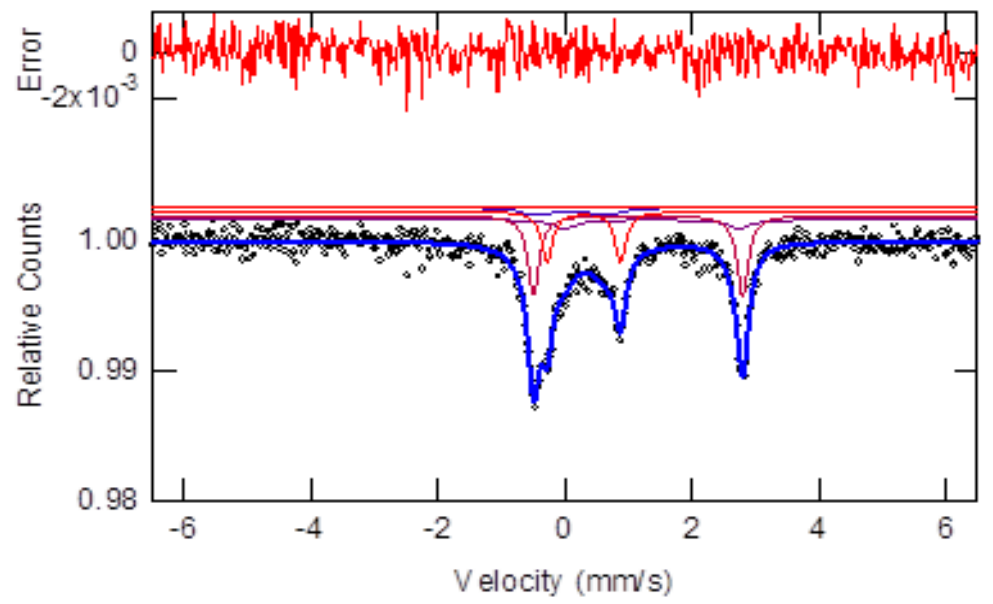

Fig. 9. Mössbauer spectra of $\left[\mathrm{FeL}_{2}\left(\mathrm{H}_{2} \mathrm{O}\right)_{2}\right]$

Table. 4: Mössbauer parameters of compounds $\left[\mathrm{FeL}_{2} \mathrm{Cl}\left(\mathrm{H}_{2} \mathrm{O}\right)\right]$ and $\left[\mathrm{FeL}_{2}\left(\mathrm{H}_{2} \mathrm{O}\right)_{2}\right]$

\begin{tabular}{lcccccc}
\hline Compound & $\begin{array}{c}\text { Spectral I; km } \\
\text { component }\end{array}$ & $\mathrm{IS},{ }^{\mathrm{a}}(\mathrm{mm} / \mathrm{s})$ & $\mathrm{QS},{ }^{\mathrm{b}}(\mathrm{mm} / \mathrm{s})$ & $\begin{array}{c}\mathrm{Fe} \text { oxidation } \\
\text { state }\end{array}$ & $\begin{array}{c}\mathrm{FWHM}^{\mathrm{c}} \\
(\mathrm{mm} / \mathrm{s})\end{array}$ & $\mathrm{S}_{\mathrm{r}}{ }^{d},(\%)$ \\
\hline$\left[\mathrm{FeL}_{2} \mathrm{Cl}\left(\mathrm{H}_{2} \mathrm{O}\right)\right]$ & Signal & +0.356 & - & $\mathrm{II}(\mathrm{HS})$ & $1.49 \pm 0.402$ & 100.0 \\
{$\left[\mathrm{FeL}_{2}\left(\mathrm{H}_{2} \mathrm{O}_{2}\right]\right.$} & Doublet I & +1.480 & 2.740 & II(HS) & $0.44 \pm 0.094$ & 16.00 \\
& Doublet II & +1.26 & 3.29 & II(HS) & $0.21 \pm 0.017$ & 36.13 \\
& Doublet III & +0.203 & 1.072 & II(LS) & $0.55 \pm 0.118$ & 25.69 \\
& Doublet IV & +0.40 & 1.151 & II(LS) & $0.22 \pm 0.040$ & 22.12 \\
\hline
\end{tabular}

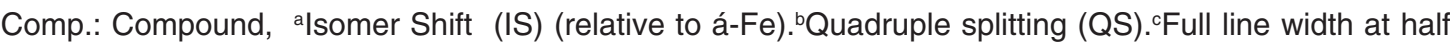
maximum $(F W H M)$, dPartial resonant absorption areas $\left(R_{A}\right)$ of spectral components which represent relative contents of the corresponding form assuming a common recoilless fraction for all forms. HS: High spin, LS: Low spin.

M3 complexes exhibit nuclease activity due to their efficient DNA binding ability.The ligand and complexes were able to convert supercoiled DNA into open circular DNA. The reaction is modulated by metallocomplex bound hydroxyl radical ${ }^{31}$.
Control does not show any cleavage. This may be due to formation of redox couple of metal ions and its behavior. Further the presence of smear in the gel diagram indicates the presence of radical cleavage ${ }^{32}$.

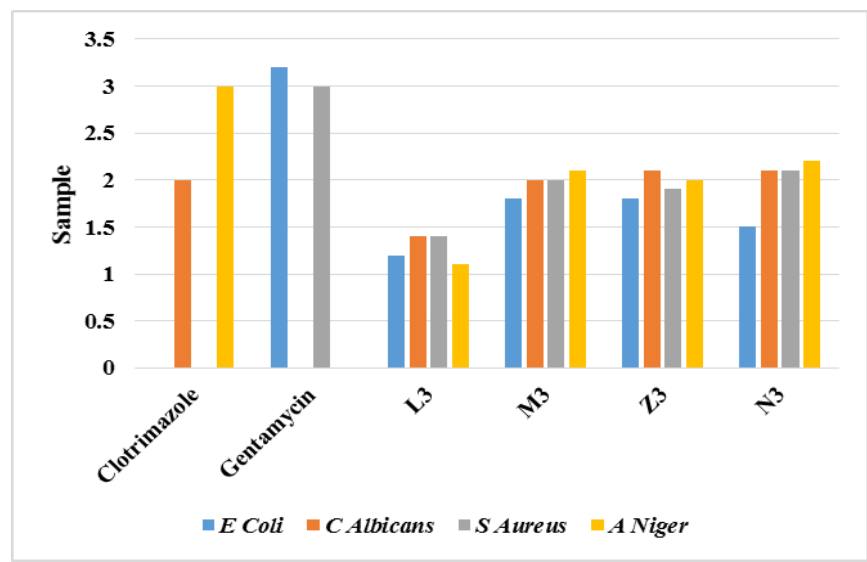

Fig.10. Antimicrobial activity of LH and its complexes 
The Co(II) complex has been tested for cytotoxic activity against two human cancer cell line $\mathrm{SiHa}$ and $\mathrm{SkBr}_{3}$. The cells revived with RPMI medium containing $20 \%$ FBS. Procedure done in laminar air flow. For sub culturing, cells are given a media change a day after they are revived. Then onwards RPMI containing $10 \%$ FBS is used. Then cells are seeded by transferring them onto 96 well plates for Hoechst staining. The drugs were added after cells attain around $60 \%$ confluency in the culture plate and apoptosis was induced in them and observed under fluorescent microscope and is given in Fig. 13 . It is interesting to observe that $100 \%$ chromatin condensation has occurred with $\mathrm{SkBr}_{3}$ and an average of $95.5 \%$ condensation happened in $\mathrm{SiHa}$ compared to that of control $32,33,34$.
The SHG efficiency of ligand and complex done by modified version of powder technique by Kurtz and Perry ${ }^{35}$. The second harmonic generation efficiency of $\mathrm{LH}$ and its $\left[\mathrm{MnL}_{2}\left(\mathrm{H}_{2} \mathrm{O}\right)_{2}\right]$ complex were determined. The efficiency of sample was compared with microcrystalline powder of KDP. LH shows 5.1 $\mathrm{SHG} / \mathrm{mV},\left[\mathrm{MnL}_{2}\left(\mathrm{H}_{2} \mathrm{O}\right)_{2}\right]$ shows $5.3 \mathrm{SHG} / \mathrm{mV}$ compared to $11 \mathrm{SHG} / \mathrm{mV}$ for KDP. The percentage efficiency of $\mathrm{LH}$ is $46.36 \%$ and for $\left[\mathrm{MnL}_{2}\left(\mathrm{H}_{2} \mathrm{O}\right)_{2}\right]$ it is $48.18 \%$ with respect to KDP. Mn(II) complex shows enhanced activity compared to LH. The experimental data infers that ligand and complex are less active. Though the present investigated azodye and its complex possesses a pathway of conjugated electrons the NLO activity is low and this may be due to absence of electron pushing and pulling substituents on aromatic rings ${ }^{36}$.

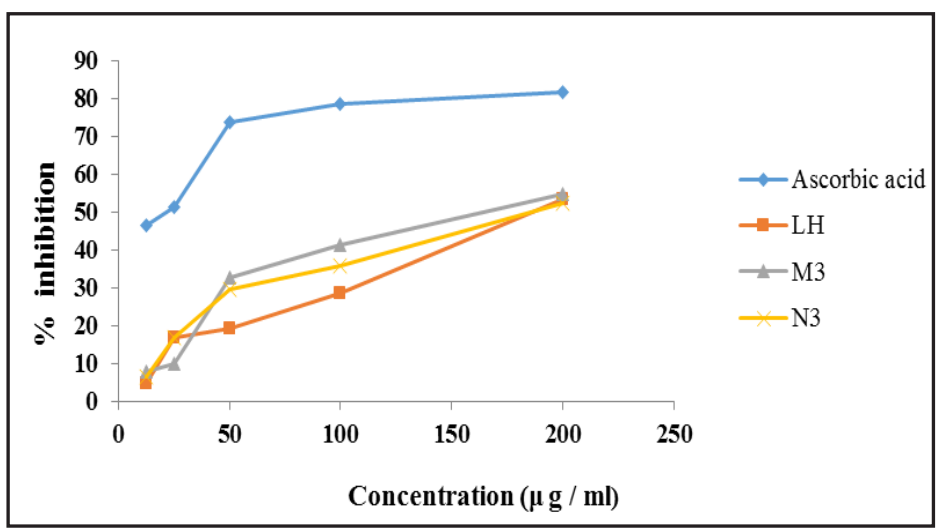

Fig. 11. Antioxidant activity

DNA Ladder $\quad$ L3 $\quad$ M3 $\quad$ N3

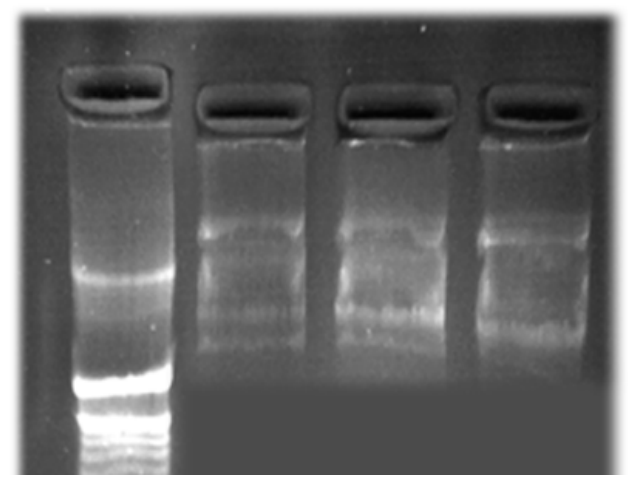

Fig. 12. DNA cleavage

\section{CONCLUSION}

The coordination chemistry of ligand 3-hydroxy-4-(2,4-dihydroxyphenylazo)naphthalene1 -sulphonic acid has been investigated Analytical

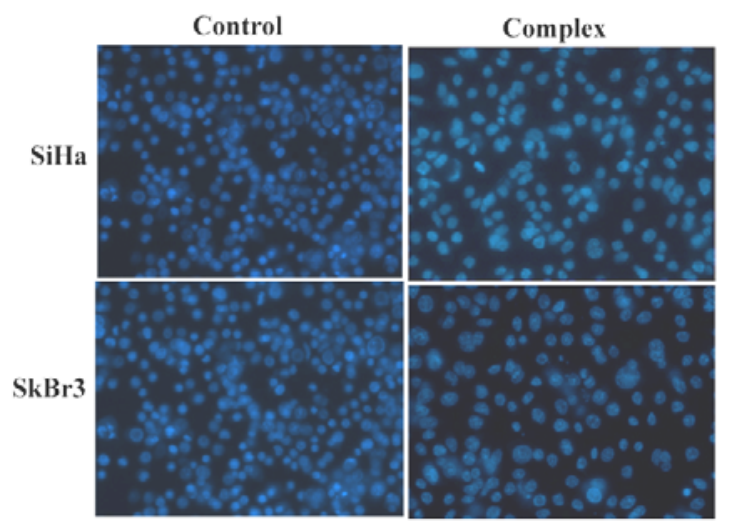

Fig. 13. Cytotoxic activity

data shows that in all complexes the metal ligand ratio are 1:2. The conductance value suggest that all complexes are non-electrolyte in nature. The hydroxyl proton of LH appeared at $11.10 \mathrm{ppm}$ is absent in $\mathrm{Zn}(\mathrm{II})$ complex, which supports the 
deprotonation of one $\mathrm{OH}$ group. The other NMR signals are shifted to lower field indicating the ligand chelation. The mass spectrum of $\mathrm{LH}$ and $\mathrm{Zn}$ (II) complex agrees well with the analytical data obtained. The infrared spectra of complexes indicates that $\mathrm{LH}$ acts as univalent bidentate ligand. Infrared spectral data also support the presence of coordinated water molecule in all complexes except for $\mathrm{Zn}(\mathrm{II})$. The mass spectrum supports this observation. The coordination centers are azo nitrogen and phenolic oxygen after deprotonation. All complexes exhibit octahedral geometry except for $\mathrm{Zn}$ (II) complex which is tetrahedral. This is further evidenced by electronic spectra and magnetic moment values. . IR spectral data suggest univalent bidentate chelation of ligand and coordination sites are azo nitrogen and phenolic $\mathrm{OH}$ after deprotonation. The $\mathrm{Mn}(\mathrm{II})$ and $\mathrm{Ni}(\mathrm{II})$ complexes show enhanced fluorescence. The NLO activity of $\mathrm{Mn}$ (II) complex is comparatively higher compared to the ligand. The metal complexes have enhanced antimicrobial activity than ligand. Antioxidant property of the ligand and complexes also studied. The interaction of ligand and complexes with DNA was investigated by gel electrophoresis. It is observed that ligand and complexes cleave DNA as compared to control in the presence of $\mathrm{H}_{2} \mathrm{O}_{2}$. This report has also highlighted the importance of Co(II) complex for anticancer activity.

\section{ACKNOWLEDGMENT}

The authors are thankful to RGCB, Trivandrum, for cytotoxic studies and Department of Chemistry, University College, Trivandrum for instrumental facilities under DST FIST. I author is thankful to UGC for the FDP support.

\section{REFERENCES}

1. Mahovadiya, V. A. Synthesis characterization spectral studies: Biocidal activities of $\mathrm{Fe}$ (II) and $\mathrm{Cu}(\mathrm{II})$ complexes of azo dye ligand derived from sulfamethoxazole and substituted p-cresol. Orient. J. Chem., 2012, 28(2), 921-925.

2. Pooja, T.; Malay, C. Decolourisation of metal complex azo dyes and treatment of a dye house waste by modified photo-Fenton process. Indian. J. Eng. Mater. Sci., 2004, 11, 499-504.

3. Dakiky, M.; Nemcova, I. Dyes and Pigm., Aggregation of o, o'-Dihydroxy azo dyes III. Effect of cationic, anionic and non-ionic surfactants on the electronic spectra of 2hydroxy-5-nitrophenylazo-4-[3-methyl-1(43-sulfophenyl)-5-pyrazolone]., 2000, 44(3), 181-193.

4. Torres, E.; Bustos-Jaimes, I.; Le Borgne, S. Potential use of oxidative enzymes for the detoxification of organic pollutants. Applied Catalysis B., 2003, 46(1), 1-15.

5. Yousefi, H.; Yahyazadeh, A.; Reza Yazdanbakhsh, M. Synthesis, spectral features and biological activity of some novel hetarylazo dyes derived from 6-amino-1,3dimethyluracil. J. Mol. Str., 2012, 1015, 27-32.

6. Demirbas, A.; Sahin, D.; Demirbas, N.; Karaoglu, S. A. Synthesis of some new 1,3,4thiadiazol-2-ylmethyl-1,2,4-triazole derivatives and investigation of their antimicrobial activities. Eur. J. Med. Chem., 2009, 44(7), 2896-2903.
7. Myrna, S.; Aida, S.; Norberto, M. Microbial decolouration of azo dyes. A review Process Biochemistry., 2012, 47, 1723-1748.

8. Rinde, E ; Troll, W., Metabolic reduction of benzidine azo dyes to bezidine in Rhesus monkey, J. Natl. Cancer Inst., 1975, 55, 81.

9. Shiro Matsoka, Kazuhisa, Y. Analytica Chimica Acta., Development of a Single Fluorescence-Based Optosensor for Rapid Simultaneous Determination of Fungicides Benomyl and Thiabendazole in Waters and Commercial Formulations. 2010, 664, 1-18.

10. Carmen Lopez, Anne -Gaelle Valade. Mechanism of enzymatic degradation of the azo dye Orange II determined by ex situ $1 \mathrm{H}$ nuclear magnetic resonance and electrospray ionization-ion trap mass spectrometry. Analytical Biochemistry. 2004, 335, 135-149.

11. Sadasivan, V.; Alaudeen, M. Synthesis and crystalstructure of the $\mathrm{Zn}$ (II) complex of 5(2,3-dimethyl-1-phenyl-3-pyrazolin-5-one4-ylhydrazono)hexahydropyrimidine-2-thioxo4,5-trione, Indian J. Chem., 2007, 46A, 19591962.

12. Vogel, A. I. A Text Book of Quantitative Inorganic Analysis ELBS, London, 1961.

13. Swati, Prassan Singh, Romila Karnawat.; Sharma I. K.; Verma P.S. Synthesis, Electrochemical and Antimicrobial Studies of 2-Phenylazo-1-naphthol-4sulphonic acid. Int. J. Chem Tech Res., 2011, 3(3), 1164-1171.

14. Wainwright, M. Photodynamic therapy-from 
dyestuffs to high-tech clinical practice, Reverend Program Coloration. 2004, 34, 95-109.

15. Radhakrishnan, P. K.; Indrasenan, P.; Nair, C. G. R.Complexes of lanthanidenitrates with 4n-(2'-hydroxybenzylidene) aminoantipyrine. Polyhedron, 1984, 3, 67.

16. Nakamoto, K. K. Infrared \&Raman spectra of Inorganic \& Coordinaton compounds. Wiley, New York, 1978.

17. Joseph, M.; Kuriakose, M.; Kurup, M. R. P.; Suresh, E.; Kishore, A.; Bhat, S. G. Structural antimicrobial and spectral studies of $\mathrm{Cu}(\mathrm{II})$ complexes of 2-benzoylpyridine N(4)-phenyl thiosemicarbazone. Polyhedron. 2006, 25, 61.

18. Lever, A. B. P. Inorganic electronic spectroscopy, Elsevier Publ. Comp., Amsterdam, London, New York., 1984, 458-472.

19. Tudor, R.; Elena, P.; Catalin, M. Some new $\mathrm{Cu}$ (II) complexes containing an $\mathrm{ON}$ donor Schiff base: Synthesis, characterization and antibacterial activity. Polyhedron, 2011,30 , 154-162.

20. Kawade, V. A.; Kumbar, A. S.; Naik, D. B.; Butcher, R. J. Synthesis Characterisation and pulse radiolysis of $\mathrm{Co}$ (II) complexes of 2picolinate and polypyridyl ligands. Dalt.Trans., 2010, 39(24), 5664-5675.

21. Natrarajan, R.; Antonysamy, K.Synthesis, structural characterization and electrochemical and antibacterial studies of Schiff base copper complexes. Transition Met. Chem., 2004, 29, 129-135.

22. Alfred, G. Maddock. Mössbauer Spectroscopy Principles and Applications. Horwood Publishing Limited, England. 1997.

23. Ashutosh, Misra.; Rekha, Sharma. Spectroscopic studies on transition metaliron complexes of 2-(N-aryl ethanimidoyl)phenol as ligands. Indian J. Appl. Phys., 2011, 49, 745.

24. Mini, S.; Meena, S. S.; Pramod Bhatt, Sadasivan, V.; Vidya, V. G. Synthesis and characterization of $\mathrm{Fe}$ (III) complex of an azo dye derived from (2-amino-5-chlorophenyl) phenyl methanone, AIP Conf. Proc. 2013, 1536, 1011-1014.

25. Vidya, V. G.; Meena, S. S.; Pramod Bhatt,; Sadasivan, V.; Mini, S.; Spectroscopic studies on $\mathrm{Fe}(\mathrm{II})$ and $\mathrm{Fe}$ (III) complexes of 5-aryl azo substituted !H-pyrimidine-2,4-dione. AIP Conf. Proc. 2013, 1536, 1009.

26. Vidya, V. G.; Sadasivan, V.; Meena, S. S.; Pramod Bhatt,. Synthesis and spectral study of new azo dye and its iron complexes derived from 2-naphthol and 2-amino-3hydroxypyridine. AIP Conf. Proc., 2014,
1620, 622.

27. Mini, S.; Sadasivan, V.; Meena, S. S.; Pramod Bhatt.Spectroscopic studies on two mono nuclear iron(III) complexes derived from a Schiff base and an azo dye. AIP Conf. Proc., 2014, 1620, 322.

28. Mini, S.; Sadasivan, V.; Meena, S. S.; Pramod Bhatt. ; Synthesis and spectral studies of metal complexes of a Schiff base derived from 2-amino(5-chloro-phenyl)phenyl methanone. Spectrochimica Acta $A$, 2015, 151, 598-604.

29. Raman,N.;Jayamurugan, R. ; Subbulakshmi, M. ; Brominathan, R. ; Yuvarajan, C. R. Synthesis, DNA binding and antimicrobial studies of novel metal complexes containing pyrazoline derivative Schiff base. Chem. Pap., 2010, 64, 513- 524.

30. Baumann, J.; Wurm, G.; Bruchhausen, V. Prostaglandin synthetase inhibiting and O2-radical scavenging properties of some flavonoids and related phenolic compounds Naunyn-Schmiedeberg's. Archives of Pharmacology., 2002, 27, 308.

31. Prativel G, Pitic M Bernadou J and Meunier B, Angew Chem. Int. Ed. Eng., 1991, 30,702.

32. Thomas, M. K.; Naik, A. D.; Nethaji, M.; Chakravorthy, A. R. Photo-induced DNA cleavage activity of ternary ( $\mathrm{N}$-salicylideneL-methioninato)copper(II) complexes of phenanthroline bases. Indian. J. Chem, A., 2004, 43A, 691-700.

33. Abd El-Halim, H. F.; Mohamed, G. G.; ElDessouky, M. M.; Mahmoud, W. H. Ligational behaviour of lomefloxacin drug towards $\mathrm{Cr}(\mathrm{III}), \mathrm{Mn}(\mathrm{II}), \mathrm{Fe}(\mathrm{III}), \mathrm{Co}(\mathrm{II}), \mathrm{Ni}(\mathrm{II}), \mathrm{Cu}(\mathrm{II}), \mathrm{Zn}(\mathrm{II})$, Th(IV) and UO(2)(VI) ions: synthesis, structural characterization and biological activity studies. Spectrochim. Acta A., 2011, 82(1), 8-19.

34. Chen, J.; Keltner, L.; Christophersen, J.; Zheng, F.; Krouse, K.; Singha, A.;Wang, S. S. Deep technology for deep light distribution in tissue for phototherapy. Cancer Journal., 2002, 8(2), 154-163.

35. Kurtz, S. K.; Perry, T.T,A powder technique for the evaluation of non linear optical materials. J. Appl. Phys., 1968, 39, 3798-3813.

36. Patil, P. S.; Dharmaprakash, S. M.; Ramakrishna, K.; Fun, H. K.; Sai Santosh, K. R.; Narayana, R. D. Second harmonic generation and crystal growth of new chalcone derivatives. Journal of Crystal Growth., 2007, 303(2), 520-524. 